\title{
Citizens' Perception of Combined Sewer Overflow Spills into Bathing Coastal Areas
}

\author{
Eduardo Martínez-Gomariz (D). \\ Maria Guerrero-Hidalga (1). \\ Edwar Forero-Ortiz (D). Susana Gonzalez
}

Received: 7 June 2021 / Accepted: 12 August 2021 / Published online: 31 August 2021

(C) The Author(s) 2021, corrected publication 2021

\begin{abstract}
Once a wastewater treatment plant (WWTP) exceeds its capacity, it is necessary to discharge a proportion of the flow to watercourses through combined sewer overflow (CSO) structures. In coastal urban areas, CSO spills may occur in seawaters. The present study analyses the effects of these spills into urban coastal bathing areas, through a qualitative survey-based analysis in Badalona and Barcelona, focusing on stakeholders' reputation and image involved in the sewer system and beaches management (i.e. intangible damages) and the consequences for the economy (i.e. tangible damages). The direct relation between CSO spills and impacts on restaurants' revenues is not observed since business owners in Badalona and Barcelona do not perceive any economic impact due to these events. Their main concern is the municipality's image, which might affect the citizens' view of the management of the responsible agents and indirectly, the tourist sector, especially in Barcelona. Residents perception in this matter is remarkably different in both cities. In Badalona,
\end{abstract}

E. Martínez-Gomariz $(\bowtie) \cdot$ M. Guerrero-Hidalga .

E. Forero-Ortiz $\cdot$ S. Gonzalez

Cetaqua, Water Technology Centre, Cornellà de Llobregat,

Barcelona, Spain

e-mail: eduardo.martinez@ cetaqua.com

E. Martínez-Gomariz · E. Forero-Ortiz

Flumen Research Institute, Civil and Environmental

Engineering Department, Universitat Politècnica de

Catalunya, Barcelona, Spain residents know the problem and even the body responsible for setting the red flag and the beaches closure (i.e. the municipality). In Barcelona, though, residents are quite confused about this. The complexity in terms of competencies in sewer systems management requires a better communication campaign for the citizens to avoid misunderstandings and unnecessary loss of trust in the City Council. Decision-makers and stakeholders should be interested in understanding the perception of affected users upon these events to take appropriate measures to enhance awareness programs or measures to reduce overflows.

Keywords Drainage system - Combined sewer overflows · Indirect damages · Coastal pollution · Citizens $\cdot$ Intangible damages

\section{Introduction}

Drainage systems are essential urban infrastructures since they are designed to prevent flooding, reduce inconvenience due to surface water ponding, alleviate health hazards, and improve aesthetics (Marsalek et al., 1993). These infrastructures have been traditionally expanded without considering the impacts of potential discharges on receiving waters.

Two types of water must be drained from urban environments: stormwater and wastewater. Based on this, two different sewer systems can be found, combined and separate (Butler et al., 2018). The main 
features of the first are that they convey both wastewater and stormwater in the same pipe. The separate sewer system transports surface runoff by storm sewers which discharge into receiving water bodies (rivers or sea). On the other side, wastewaters are conveyed by sanitary sewers to wastewater treatment plants (WWTP), released to a watercourse after treatment.

Combined sewer systems during wet weather convey a much higher water volume than during dry weather (usually up to 3-5 times the medium wastewater volume). Once WWTP exceeds their capacity, it is necessary to discharge a proportion of the untreated wastewater and stormwater flow to watercourses through combined sewer overflow (CSO) structures (e.g. stilling ponds, high side weirs, and vortex and swirl concentrator separators). It is a common practice to avoid frequent flooding. Although a debate on using separate or combined sewer systems exists (Geels, 2006), this limitation is seen as a deep concern for this type of sewer system. Since the second half of the twentieth century, CSO spills have been identified as a significant pollution source of receiving water bodies and a public health threat, being nowadays still a concern.

There are two types of water pollution sources in urban areas: point and diffuse. The first is the wastewater coming from houses and industrial sites or collective buildings (like hospitals). The second is the wash-off of natural (unpaved) and impervious areas like roads or roofs that produces runoff flows. Point sources of water pollution present high concentrations of suspended solids, organic loads, nutrients, phosphorus, metals, and faecal bacteria. Diffuse water pollution sources exhibit a high concentration of heavy metals, hydrocarbons, nutrients, and coarse debris (Gromaire et al., 2001). Therefore, combined sewers carry a high variety of pollutants during wet weather, exposing a challenge still to be solved for many European cities. Combined sewer systems are very common in Europe. For instance, over 70\% of Spanish cities have combined sewers (Montserrat, 2015).

A European regulation aiming to protect the environment and water pollution control is the Urban Wastewater Treatment Directive (UWTD, 91/271/ EC), whose main aim is to protect the environment and human health from urban wastewater spills (Corominas et al., 2013). Although the UWTD requires the design of collecting systems to account for the pollution of CSO spills, it acknowledges the impossibility to construct sewers and treatment plants with the capacity to deal with the water volumes produced by intense rain episodes, and the control of CSOs remains unclear (Montserrat, 2015). The transposition of the UWWTD in Spain was updated through the law RD 1290/2012, which established a framework to limit the pollution of receiving water bodies by controlling runoff waters and representing a redefinition of urban drainage practices in Spain (Suárez López et al., 2014). Some of the Spanish regulation measures are aimed to better manage CSO structures, construct retention tanks to intercept the first runoff waters, and build separate sewers for new developments. In compliance with the RD 1290/2012, the Spanish Ministry of Agriculture, Food and Environment published in 2014 the Recommendations Manual for Stormwater Tanks Design (Comas et al., 2014). The manual will serve as the basis to elaborate the upcoming technical standards on stormwater tanks design (Malgrat et al., 2015; Ministerio de agricultura, 2014). The UWTD implementation contributes towards reaching the Water Framework Directive's (WFD 2000/60/EC) objectives of preserving and, where necessary, improving the quality of inland, transitional, coastal, and groundwater.

Recently, the 1991 Urban Waste Water Treatment Directive (UWWTD) was evaluated by the European Commission (2019a). In this document, it was stated that, although the UWWTD has been successful in reducing loads of the targeted pollutants from urban point sources (domestic/urban wastewater and similar industrial pollution), there is the need to address today's societal challenges, including climate change, contaminants of emerging concern, and the need to unleash better the Directive's potential to contribute to a cleaner and more circular/resource-efficient economy. One of the aims of this evaluation was to secure a better alignment of the UWWTD to the new policy objectives as defined in the Green Deal (European Commission 2019b), particularly its zero-pollution ambition.

In coastal urban areas, CSO spills may occur in seawater, which environment is regulated in this context not only by the UWTD and WFD but also by the Bathing Water Directive (BWD, 2006/7/EC). This Directive aims to allow EU citizens to benefit from clean and safe bathing waters and protect the sea waters from pollution. This Directive states the 
monitoring and classification of bathing water, the management of bathing water quality, and the provision of information to the public on bathing water quality. According to article 12, in the case of bathing waters subject to short-term pollution (e.g. CSO spills), Member States shall ensure the dissemination of notifications about the issue during the bathing season in an easily accessible place in the near vicinity of each bathing water, an indication of the number of days that bathing is prohibited or advised against during the preceding bathing season because of such pollution, and a warning whenever such pollution is predicted or present.

The Directive 2006/7/CE sets the need to monitor potential discharge points near the beach to facilitate real-time information about the bathing waters pollution and to avoid any risks for beachgoers. Article 73 from the Spanish Royal Decree 876/2014 (Ministerio de Agricultura Alimentación y Medio Ambiente, 2017), in which the General Regulation of Coasts is approved, indicates that in the stretches of coast that are not marked as a bathing area, it will be understood that it occupies a strip of sea contiguous to the coast with a width of $200 \mathrm{~m}$ on the beaches.

Therefore, the commitment of the UWTD (91/271/ EC), the implementation of the WFD, and the Bathing Waters Directive (BWD, 2006/7/EC) require the managers of urban drainage systems and WWTPs to work in a coordinated manner to reduce the pollution effects on receiving waters, especially during wet weather.

Within this complex, and living regulatory context, this study focuses on the assessment of potential impacts of the CSO spills through a qualitative analysis of the seafront business owners and residents' perception regarding this issue. The effects of CSO spills into urban coastal bathing areas have been analysed, focusing on the reputation and image of the stakeholders involved in the sewer system and beach management (i.e. intangible damages) and their consequences for the economy (i.e. tangible damages). Two neighbouring Spanish coastal cities (Barcelona and Badalona) were selected as the case studies in the framework of the EU-funded projects RESCCUE and BINGO, respectively. In this study, seafront business owners and residents from both cities were surveyed, and their responses have been analysed and compared. Intangible damages may occur when citizens lose trust in the stakeholders involved in managing the sewer system and bathing waters and beaches and the consequent effect on their reputation and image. Citizens' view in this regard was investigated through the residents understanding of CSO spill events. The number of days of non-compliance with the BWD (bathing is forbidden and the beach is closed) in a representative period (bathing season) was considered an indicator. Tangible damages were also addressed since CSO spills might affect different sectors, such as tourism, fishing and leisure, and those impacts can be recognised as direct damages. It is noted that $24 \%$ of the Spanish coast are beaches, and $82 \%$ of the tourist population in Spain is concentrated in coastal areas (España, 2015); thus, these impacts (i.e. direct and indirect damages) could be relevant nationwide. Decision-makers and stakeholders might be interested in understanding the perception of affected users upon these events to take appropriate measures to enhance awareness programs or measures to reduce overflows.

This paper's following sections include (2) methods and materials; (3) results and discussion, and (4) conclusions. Section 2 (Methods and Materials) presents the case studies' description (Barcelona and Badalona) and the survey campaign's design. Section 3 (Results and Discussion) encompasses the surveyed groups' responses (seafront business owners and residents) and discusses the outcomes regarding the matter's overall perception. Finally, Sect. 4 (Conclusions) gathers some take-home messages and the main benefits of the presented research are recalled.

\section{Methods and Materials}

\subsection{The Case Study Description: Barcelona and Badalona}

The Barcelona Metropolitan Area (AMB) is the supramunicipal government responsible for the 36 municipalities that make up the metropolitan area of Barcelona (Catalonia, Spain). The two selected coastal municipalities, Badalona and Barcelona, are two of them. The AMB manages the conveying and treatment of wastewater processes from connection points with the municipal sewer system up to treatment plants (main sewers, Fig. 1). Most of the sewer networks in the metropolitan area of Barcelona are 
Fig. 1 Beaches and CSO structures location for Barcelona and Badalona (Spain)

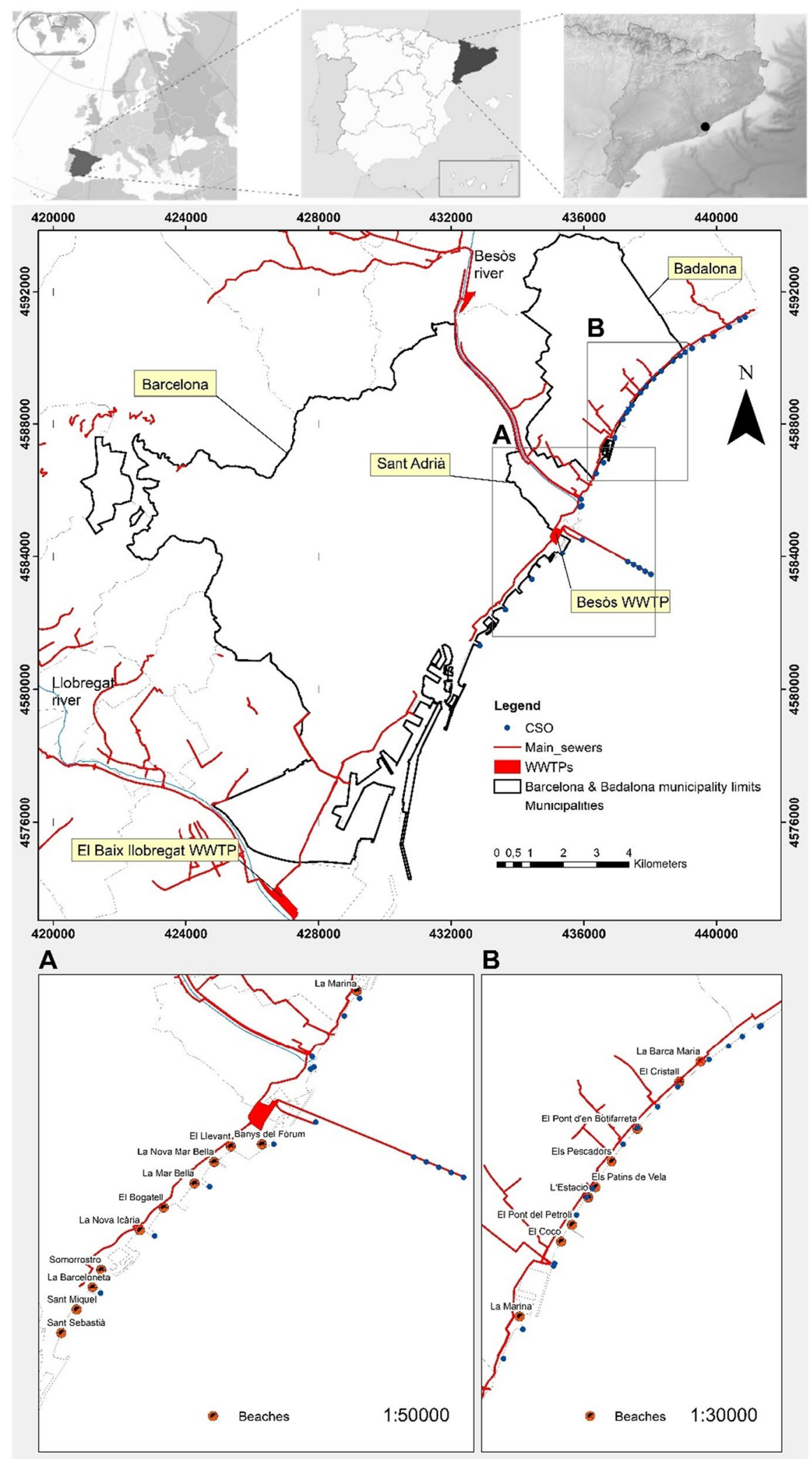


combined. It presents $93 \mathrm{CSO}$ structures in the entire drainage system that discharge mixed waste and stormwater to different receiving bodies during rainfall episodes. Therefore, AMB is accountable for the consequences of combined sewer overflow spills that affect specific points of the coastal municipalities of Barcelona and Badalona. CSO structures within Barcelona and Badalona are located in the main sewer along the coast, which receives wastewater and stormwater from municipal sewer networks and conveys them to the Baix Llobregat WWTP and the Besòs WWTP (Fig. 1). The El Baix Llobregat WWTP is situated in the municipality of El Prat de Llobregat. It is one of Europe's largest and most modern WWTP and treats a quarter of the wastewater from Barcelona and another eight municipalities. The Besòs WWTP is located on the coast, between the municipalities of Barcelona and Sant Adrià, and has the highest treatment capacity in Catalonia. It treats the wastewater from the other three-quarters of Barcelona city and serves also Badalona and four other municipalities.

Figure 1 shows that 4 and 13 CSO structures discharge into Barcelona and Badalona's beaches, respectively. All of them are located in the main sewer, which conveys wastewater to the Besòs WWTP.

Both cities are highly urbanised, and most of the urban areas are relatively flat, a few tens of meters above mean sea level. They have a Mediterranean climate with mild winters and warm summers. The yearly average rainfall is approximately $600 \mathrm{~mm}$, and it is not rare that $50 \%$ of the annual precipitation occurs during two or three rainfall events. These rainfall patterns, together with the old and mostly combined drainage system, the high degree of imperviousness and the terrain slopes, cause frequent urban pluvial floods and combined sewer overflows (CSOs). Every bathing season, several CSO spill events occur, and the seawater quality might not comply with bathing water quality standards, according to the Bathing Water Directive (BWD, 2006/7/EC), up to a few days after CSO events. Besides, these events might cause significant intangible damages to the environment, people's safety, and the image and reputation of the stakeholders involved in the sewer system and beaches management and tangible damages to specific economic sectors (tourism, leisure, fishery, among others).

\subsubsection{Barcelona}

This city was one of the three research sites across Europe (Barcelona, Bristol, and Lisbon) of the EU project RESCCUE (RESilience to cope with Climate Change in Urban arEas - a multisectorial approach focusing on water (2016-2020)).

Barcelona municipality has a population of 1,620,943 inhabitants and a municipal area of 101.4 $\mathrm{km}^{2}$, and its average population density is 15,992 inhab $/ \mathrm{km}^{2}$. It is surrounded by the mountain range of Collserola, the Llobregat River to the south-west, and the Besós River to the northeast.

Barcelona has ten beaches (Banys del Fòrum, Llevant, Nova Mar Bella, Mar Bella, Bogatell, Nova Icària, Somorrostro, Barceloneta, Sant Miquel, Sant Sebastià) along $4.5 \mathrm{~km}$ of coast (Fig. 2). All of them belong to the districts of Ciutat Vella and Sant Martí and form the city's largest area for recreation. The beaches are one of the biggest tourist attractions, and they were visited in 2018 by approximately 3.8 million people. During rainfall events (usually higher than only a few millimetres), CSO spills occur along Barcelona's shores.

\subsubsection{Badalona}

This city was one of the six research sites across Europe (Portugal, Spain, Cyprus, Germany, the

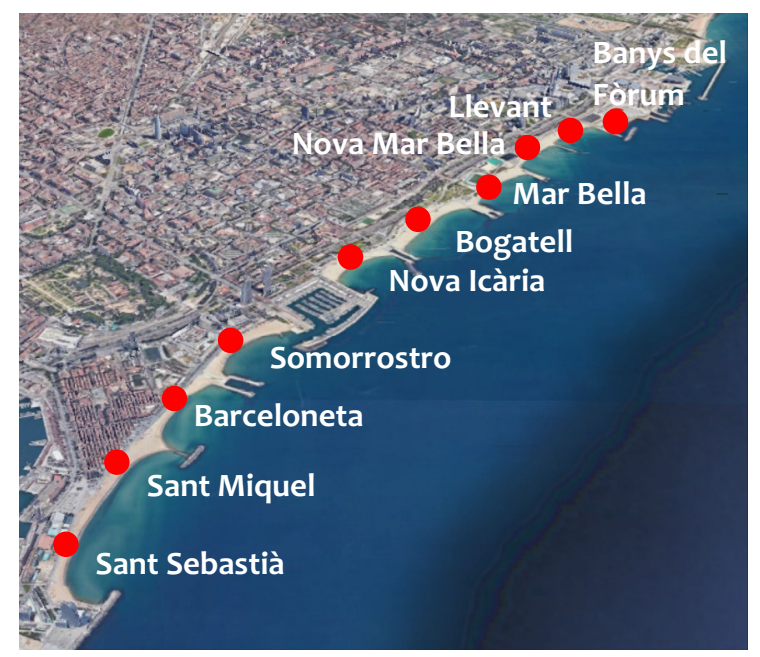

Fig. 2 Barcelona (Spain) beaches affected by CSO spills during wet weather 
Netherlands, and Norway) of the EU project BINGO (Bringing Innovation to Ongoing water management - a better future under climate change (2015-2019)). Badalona has more than 215,000 inhabitants, the third-largest municipality in Catalonia. Its administrative limits are more than $21.2 \mathrm{~km}^{2}$, and its average population density is approximately $10,000 \mathrm{inhab} / \mathrm{km}^{2}$. It is situated on the left bank of the Besòs River, facing the Mediterranean Sea and backed by the Serra de la Marina mountain range.

Badalona has nine beaches (La Marina, Coco, Pont del petroli, Estació, Patins de Vela, Pescadors, Pont d'en botifarreta, Cristall, Barca Maria) along $5 \mathrm{~km}$ of the coast (Fig. 3), which were visited by approximately 860.000 people in 2018. However, unlike Barcelona, Badalona beaches are more frequented by residents than by tourists. This means that beachgoers have more local knowledge and tend to be more concerned about aspects such as seawater quality since these aspects are affecting part of their hometown. In Badalona, during even small rains, CSO spills occur through the fifteen CSO structures located along Badalona's shores. The residents' awareness and concerns can be seen in social networks where citizens and local environmental groups attribute responsibilities to the governmental authorities (Fig. 4).

\subsection{Survey Campaign Design}

The survey aimed to assess the indirect impacts of CSO spills into Barcelona and Badalona's bathing coastal areas. This assessment was accomplished through a qualitative evaluation of the perception of different groups of the population about CSO events: residents, beachgoers, and business owners. The focus of the first group was to understand how they perceived the health risk of bathers and to what extent a loss of reputation might affect the public authorities responsible for managing sewer networks. The second group's survey led to understanding how CSO spill events may affect, from an economic point of view, the different coastal activities (hospitality, fishery, and water sports). The survey campaign's methodology and scope are now described, together with the relevant aspects of surveying.

\subsubsection{Methodology and Scope}

The methodology uses primary data obtained from telephone surveys collected amongst Barcelona and Badalona beachgoers and in-person interviews with business owners of the relevant area (Table 1). The geographical scope of the sample was limited to the bathing areas where there are discharge points. Only respondents who mentioned that they visited one of the affected beaches were invited to continue the survey. Similarly, the interviews were carried out in businesses located in affected areas.

The telephone survey consisted of a 10 -item questionnaire administered to 100 and 150 randomly selected individuals from a Badalona and Barcelona database, respectively. The first part of the
Fig. 3 Badalona (Spain) beaches affected by CSO spills during wet weather

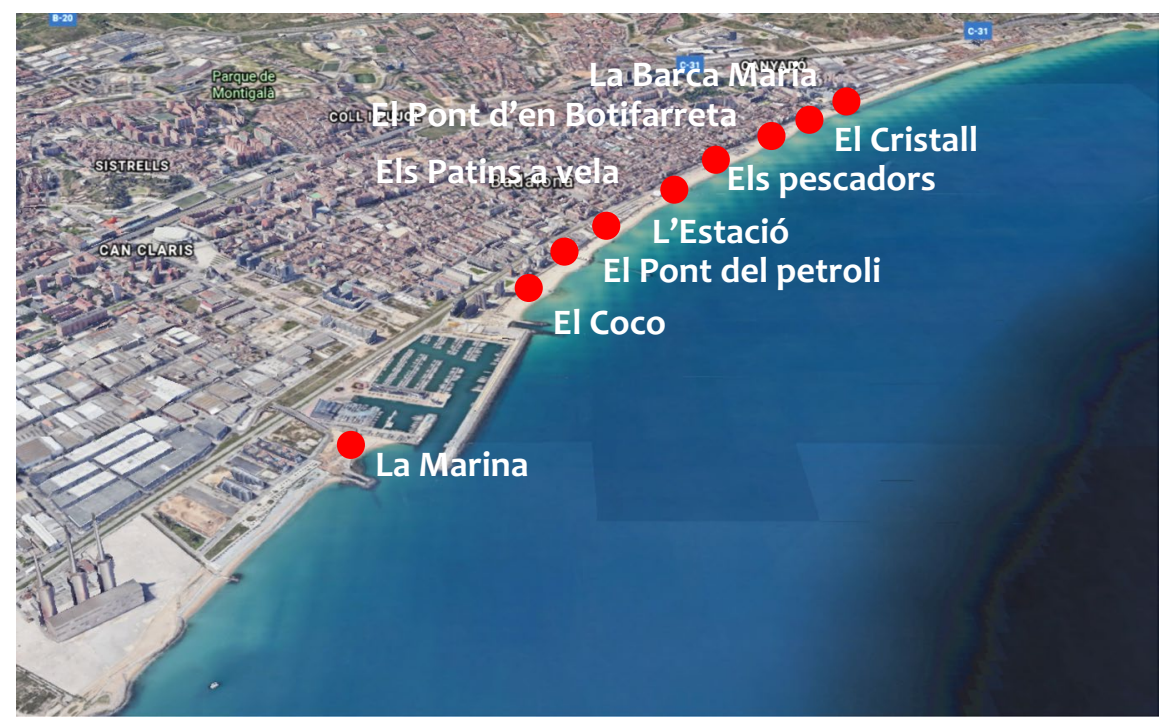


PBadalona mar@BadalonaMar.1 ago.

Whoever thought it was a good idea to connect sewage to the sea can try it out on our magnificent $5 \mathrm{KM}$-long beach in \#Badalona

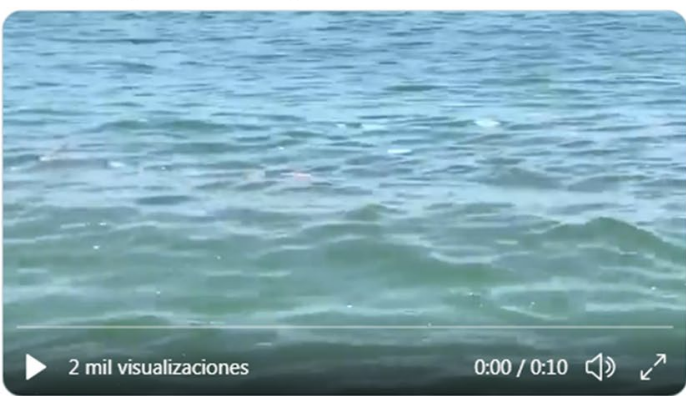

De pere 8
Q 1
〔ๆ 7
O 9
$\uparrow$

PBadalona mar @BadalonaMar.27 jul.

We must act against untreated sewage and wet wipes flowing into our seas! What will you do?

\#PlasticPollution \#PlasticWaste \#PlasticFreeJuly \#ZeroWaste \#Badalona

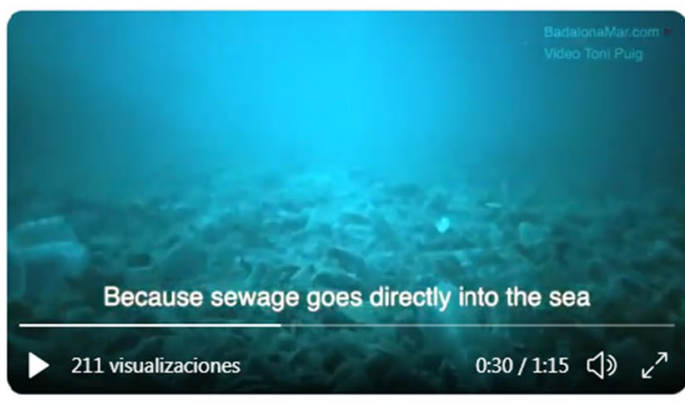

Q 2

$\uparrow \downarrow 2$

13

个

Padalona mar @BadalonaMar.27 jul.

Video was taken here: $41^{\circ} 26^{\prime} 13.0^{\prime \prime} \mathrm{N} 2^{\circ} 14^{\prime} 45.0^{\prime \prime} \mathrm{E}$ in \#Badalona, \#Barcelona right next to a sewage discharge point.

Wet wipes, plastic and sanitary waste is a result of continued untreated sewage discharges into the sea.

Q

七

O 1
PBadalona mar@BadalonaMar.1 ago.

Our own senses tell us it's not safe to swim in these conditions.

There are the usual health risks associated with sewage, which may cause gastroenteritis, conjunctivitis, otitis.

Public health risks may be increased now with COVID-19.

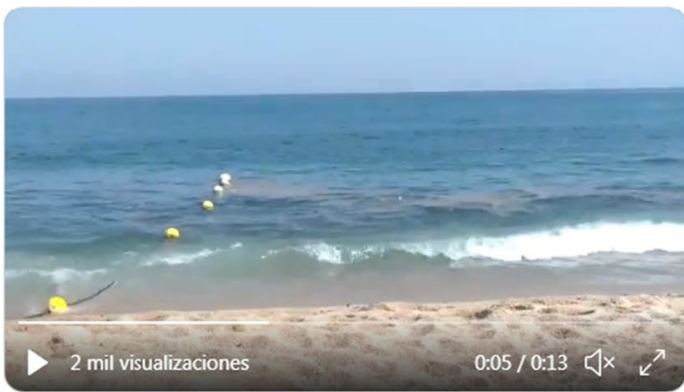

De Marta Caballé
Q 1
〔】 8
O 8
个

Padalona mar@BadalonaMar.26 jul.

Recordeu aquest vídeo? Demà farà un any des de la seva publicació.

Des de llavors no hem parat de lluitar per un mar net i sa.

Agraïm l'ajut de totxs els nostres seguidorxs! \#Badalona $C \approx 0$

2 Toni Pc II*II \& @PutxiNellii.27 jul.2019

En aquests moments, a la platja de Badalona, i com cada cop que plou... La manca de diposits pluvials i la manca de reparació del collector que porta anys rebentat, fan que les aigües residuals desemboquin a la platja. Més plàstics, contaminació i despreci absolut per la natura

Mostrar este hilo

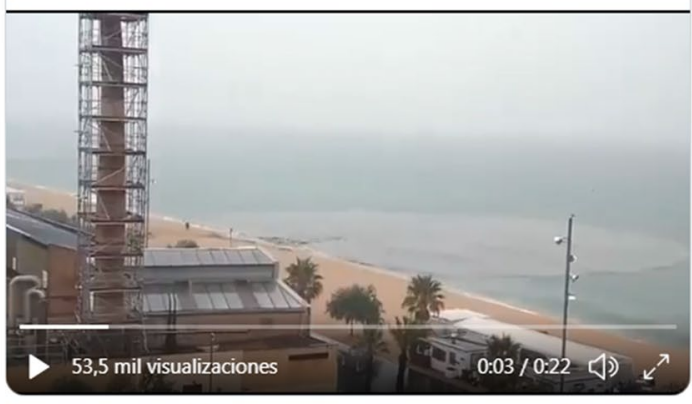

๑ 9 9 $\bigcirc 35$ 个

Fig. 4 Some tweets complaining about the frequent CSO spills in Badalona by the platform Badalona mar (@ BadalonaMar)

questionnaire assessed the sample's suitability (e.g. whether the respondent visited one of the beaches involved) and demographics (age and gender) to secure a representative sample. The second part evaluated the behaviour (e.g. reasons for visiting), and the third section measured awareness and perception of the CSO spill events. The telephone survey method was selected because it was conducted outside the bathing season, so no many people was expected to be on the beach.
The qualitative interviews assessed the business owners' awareness of CSO spills and in which extent they were impacted by them. They were carried out to owners of restaurants, owners of nautical sports, and fishermen. All of them ran their business at beaches of interest.

Analysis of the results was performed using standard qualitative and quantitative survey tools and related literature to: 
Table 1 Description of surveys and intended results

\begin{tabular}{|c|c|c|c|c|}
\hline Target population & Municipality & $\begin{array}{l}\text { Specific target population and } \\
\text { sample size }\end{array}$ & Type of survey & Results \\
\hline \multirow[t]{2}{*}{ Seafront business owners } & Badalona & $\begin{array}{l}\text { One fisherman } \\
\text { One water-sports business } \\
\text { Two restaurants }\end{array}$ & \multirow[t]{2}{*}{30 min personal survey } & \multirow{2}{*}{$\begin{array}{l}\text { - Knowledge of the event } \\
\text { - Impact (negative) of the } \\
\text { event: } \\
\text { O Environmental } \\
\text { O Health } \\
\text { Economic } \\
\text { Business and munici- } \\
\text { pality image } \\
\text { - Appraisal of the man- } \\
\text { agement of the authori- } \\
\text { ties regarding CSO } \\
\text { spills issues }\end{array}$} \\
\hline & Barcelona & $\begin{array}{l}\text { Two fishermen } \\
\text { Two water-sports business } \\
\text { Two restaurants }\end{array}$ & & \\
\hline \multirow[t]{2}{*}{ Residents } & Badalona & $\begin{array}{l}100 \text { residents over } 18 \text { years } \\
\text { old }\end{array}$ & \multirow{2}{*}{$\begin{array}{l}\text { CATI - Computer Assisted } \\
\text { Telephone Interviewing: } \\
\text { semi-structured question- } \\
\text { naire (10-min duration) }\end{array}$} & \multirow{2}{*}{$\begin{array}{l}\text { - Knowledge of the event } \\
\text { - Level of satisfaction } \\
\text { with the water quality } \\
\text { of the beaches in the } \\
\text { municipality } \\
\text { - Trust in the public } \\
\text { authorities }\end{array}$} \\
\hline & Barcelona & $\begin{array}{l}150 \text { residents over } 18 \text { years } \\
\text { old }\end{array}$ & & \\
\hline
\end{tabular}

- Understand personal experiences and impacts caused by beaches closure due to low seawater quality

- Know their personal view of the authorities management of CSO spills issues

The survey quality control was carried out according to ISO 20,252 (2019) and the International Code of Conduct ICC/ESOMAR (2016). The telephone sampling error was $+6.32 \%$ for a probability of not being exceeded $95.5 \%$ and maximum indeterminacy $(p=q=0.5)$ for the reference universe. The sample allocation was proportional to the universe with crossed quotas for age, sex, and residential district. The qualitative in-person surveys of business owners and fishermen are not considered as a representative sample of the entire universe, so no errors or statistics were evaluated. The limited number of in-person interviews was due to the constrained resources available. Although indicators such as distance from the beach are acknowledged to be important regarding beach usage, the present study does not take it into account.

\subsubsection{Relevant Aspects of Surveying}

The survey questionnaire was designed to address the most relevant aspects to assess the impacts of combined sewer overflow spills into Barcelona and Badalona's bathing coastal areas. The following topics are listed:

- Frequented beaches in Barcelona and Badalona

- Type of activities undertaken at the beach

- User willingness to find out about the conditions of the beach and the sea

- Means to obtain information about the status of the beach

- User reaction if informed the red flag is raised

- User opinion about the reason for a raised red flag

- Responsible for deciding the colour of the flag indicating the state of the sea

- Level of satisfaction with the water quality of the beaches in your municipality

- Knowledge of the existence of a red flag due to CSO spills after rainfall events

- User encounter of any beach closure (red flag) because of CSO spills

- User opinion about the responsible for seawater pollution caused by CSO spills into the coastal bathing area

- User agreement regarding beach closures due to CSO spills into batching coastal areas

Regarding the qualitative survey, the questions addressed to business owners and fishermen are 
aimed at understanding: (1) to what extent they know these events, (2) the impact of the event on their businesses, and (3) their assessment of the activities carried out by the City Council.

\section{Analysis of results}

The results of the survey are presented in this section broken down into both target population groups: seafront business owners and residents. For the first group, results regarding knowledge of the event, the impact (negative) of the event, and their appraisal of the authorities' management regarding CSO spills issues are presented and analysed. Residents who visit beaches in Badalona and Barcelona were surveyed to understand their knowledge of the event, their level of satisfaction with the beaches' water quality in the municipality, and their trust in the public authorities, whose results are summarised here. Finally, a discussion about the interviewees' answers is provided, and the differences between both municipalities are highlighted.

\subsection{Seafront Business Owners}

The 30-min individual survey results to fishermen and the owners of water-sports businesses and restaurants (Table 1) located on the seafront of Badalona and Badalona are presented.

\subsubsection{Badalona}

The people interviewed have adequate knowledge of CSO events, experience gained over several years of discharge events from the sewerage system into the sea, their causes, and the extent of the events with direct repercussions on their businesses.

They also relate CSO events as rain-related events, without necessarily requiring heavy rainfall to cause excess flow and subsequent discharge of untreated water to the sea. Therefore, they directly relate the discharge event frequency to the frequency of rainfall during the year, with the highest incidence of rain between October and April, coinciding with the months of the heaviest rainfall characteristic of the Mediterranean area (Krichak et al., 2000).

The three targets interviewed are concerned about the situation and are critical of the legislation and management of untreated wastewater discharged into the sea after rainfall events.

The interviewees are aware that the discharge of untreated water from the sewer system into the sea pollutes the seawater, which damages biodiversity and the aquatic ecosystem, accelerating the destruction of some species and the proliferation of others considered harmful (e.g. algae, jellyfish).

Many toxic substances from the mix of wastewater and stormwater that end up in the sea can directly impact human health and cause illness, according to the interviewees. In the case of businesses where there is direct contact with seawater (e.g. those that rent out beach areas, practice water sports, among others), they are especially concerned and cautious about this pollution to avoid damaging their customers and subsequent claims from them.

The interviewees were not able to offer an economic assessment of the impacts of these CSO discharge events. Still, the coastal sports businesses and fishermen could associate such circumstances with a reduction of their revenues. Restaurant owners did not perceive an economic impact due to the overflows.

Their economic activities are seasonal and very dependent on good weather with higher income between April and October. A rain event is in itself a financial loss for them, which is further aggravated by the subsequent closure of bathing due to water pollution.

The interviewees draw attention to the problems linked to the negative image that discharge events have for their businesses and municipalities. The pollution, often visible to the naked eye, alerts and casts doubt on the water's state from both locals and tourists. They stated that these events can cause longterm detrimental effects, such as a more significant decrease in income, by causing the displacement of users from Badalona beach to other municipalities nearby with better water quality. No data to substantiate any decrease in business was provided.

At a general level, opinions reflect some improvements in pollution management by the discharge of untreated water from the sewage system into the sea after rainfall events, compared to past events. They did not specifiy over what period these improvements were reached.

One of the actions taken after CSO events indicated by the interviewees is the closure of the bathing area warned by the red flag, which they consider 
to be taken by the City Council and define the Red Cross as the executor of the action. However, this measure is seen as valuable in order to protect the population, but not sufficient. The general perception is that water pollution is not only on the day of rain but also on the following days. Nevertheless, on those days, the bathing warning is communicated through a yellow flag, or even the flag may be green, despite the apparent seawater pollution. These comments point to a certain laxity of water quality criteria to avoid losing the blue flag (i.e. that the beach meets the optimal conditions for bathing and activities), thus losing tourist and economic activity related to the sea.

They do not know the required water quality levels that would allow bathing activities to be carried out without the risk of pollution. However, they sometimes disagree with the authorities. In extreme sea pollution cases such as CSO events, occasionally, the officer in charge of defining the flag indicating water quality chooses blue or even green flags, meaning acceptable bathing water quality; in some cases, the flag should be red from the interviewees' point of view.

On many occasions, the businesses bordering the beach, especially those with direct activities with the sea, advise the likelihood of having a sea bathe through their measures, such as cameras observing the seawater state, their colour-code flags, and direct warnings to their customers about the state of the sea.

From the perspective of the community interviewed, the CSO events need to be dealt with effectively by implementing measures that act on the problem and not the consequence. For instance, they propose changes in the sewer system so that rainwater and wastewater can be treated separately, in their own words, canalisation systems. They also suggest improving the transmission of information between responsible bodies (according to the interviewees, the municipality) and their businesses and other stakeholders, counting on the authorities involved to communicate actively and provide data on the state of water quality, facilitating better coordination between the municipality (according to them, the body responsible for discharges) and businesses.

Table 2 gathers some of the individual statements related to the different surveyed aspects for business owners and fishermen in Badalona.

\subsubsection{Barcelona}

In a general and homogeneous way, knowledge of the event is observed among the three business profiles interviewed in Barcelona. Their statements cite the discharge of untreated water from the sewer system into the sea as a joint event due to a rain episode.

On the other hand, the difficulty is perceived in determining the event's frequency; they place it between April and October, coinciding with the highest rainy season in the municipality but without an exact idea of the number of days during the season. Besides, they present an unclear identification of those responsible for the beach closure.

The consequent assessment made regarding the beach closure with a red flag due to the discharge of untreated water differs between the types of businesses, identifying two differentiated profiles:

- Profile 1: Businesses or activities that depend directly on the sea (i.e. water-sports businesses and fishermen)

- Profile 2: Businesses not directly dependent on the sea (i.e. restaurants)

Interviewees from profile 1 have better knowledge of the causes and effects of the discharge into the sea of untreated water on their activity. They will be strict and demanding in their opinion. Interviewees from profile 2 know about the event, but without substantial implications for their businesses. This different perception of the event led us to assess the impact for each profile.

Businesses or activities that depend directly on the sea (profile 1): for this profile, CSO spills into the sea without prior treatment are dangerous due to the amount of pollutants, both solid and dissolved, that impact negatively on the flora and fauna of the marine ecosystem and put them at risk. This profile identifies a CSO spill as a toxic action that facilitates the transmission of diseases, especially relevant for those who practice nautical sports in direct contact with the water since they have suffered gastrointestinal virus episodes. They recognise a direct impact on their business without explicit references to the exact economic value that this may entail. Being aware of a CSO event, they offer alternative options to those days after the rain. These alternatives can compensate for the possible fall in sales due to rejection or 
Table 2 Some individual statements of seafront business owners and fishermen in Badalona

Knowledge of the event

Impact (negative) Environmental of the event

Health

Economic

Business and municipality image

Appraisal of the administrative authority management of CSO spills issues
"From our experience, we know that when it rains, up to 2 to 3 days later, the water will be contaminated"

"When it rains, the valve in the relief pipes opens, and the feces and water flow untreated into the sea"

"When it rains, the sewage treatment plant cannot treat the water as it should, and so the sea is left in a shitty, filthy state for about 2 to 3 days"

"When 10 to $15 \mathrm{~L}$ of rainfalls, which is nothing, the sewage treatment plant closes the collector's inlet, which causes it to discharge into the sea, otherwise the collector would break from the pressure"

"As long as it rains a little bit continuously, the next day the sea is already dirty, it is possible to find rats!"

"It rains very little here in winter. Right now, the collector is full. The first rainy day in Badalona in spring will be a disaster. They will have to close the beach for 3-4 days"

"From the Mapfre Towers to Badalona is considered a dead zone, because the sea is so polluted that it has choked the oxygen and there is no life at all, there is a layer of half a meter of mud and shit (sanitary towels, plastics, etc.)"

"We can no longer fish nearby; we must take the boat $10-15 \mathrm{~km}$ out to sea; there is misery here"

"Sometimes we must veto activities in the sea for health and safety reasons, especially with minors, we give adults advice and decide, but we cannot take any risks with the little ones"

"Suppose we have a race in the open sea, and the day before it rains, we must cancel it. In that case, we have to return the registration money to the participants, return the money spent on taking out personal liability insurance for each participant, all our structure that we have for that day, the initial promotion we have done, all these factors represent money lost"

"When we cross this part of the sea full of shit with the dinghy, we have to stop the engine, and the dirt wraps around the circuit; we cannot throw the fishing net because it gets tangled up, it damages the fishing equipment"

"We offer sports camps in summer for 100 children per week, and if there are days when we cannot do the sea activities because of pollution, it may be that the other years they do not sign up for our activities"

"Sometimes we must go fishing to Castelldefels or Delta del Llobregat; you take the boat and go straight there. I do not even think about looking at the state of the sea in Badalona"

"Between the pressure we exert and the pressure from the ecological sector, we have done better, not totally well, but there is still a job to be done"

"They cheat everybody; if they show the red flag for more days, they can lose the blue flag"

"It is a farce; they take water samples from here and there, and is it always of perfect quality? However, we already see that it is not, as the sewage discharge network is full of shit, you can see that it is dirty water discharged into the sea"

"Although we do not see the stain, the seawater may be polluted, we do not analyse the water, my criteria are subjective, and the City Council is objective"

"Parallel to the flags that are put on public beaches, we have our flags. We explain it clearly. For example, the City Council flag is green many times, but when it rains, we know that there is pollution there, and we put the red flag on our facilities"

"The problem is not that the beach is closed, but why it is turned down, it is clear that if the seawater is dirty, you cannot recommend bathing and you put the necessary flag, but this problem must be fixed at the root"

"It is true that when we have asked for something, the City Council communicates with us, but we always must go ourselves. We organise an annual sea race in the open sea, we are the ones who get in touch with the beach technician, and he makes the report assuring us that the beach is not polluted, but if they already know that the race is planned, they could anticipate our requests. We do not have a direct channel with the beach administration" 
cancellation of bookings. The interviewees see this as an apparent, observable problem, they refer to a "brown spot that approaches the coast and smells", damaging the municipality's image as a tourist destination and their local visitors. They state that a city like Barcelona, considered cosmopolitan and modern, cannot afford to show this image of its beaches.

Businesses not directly dependent on the sea (profile 2): although the businesses are located on the beachfront, their main activity is not directly involved with the seawater. It is an activity more affected by the weather than by polluted water. The beaches' closure with a red flag due to CSO spills affects them in terms of smell and visualization without this being linked to an apparent decrease in revenues. They do not have records of cancellations for this specific reason. Therefore, the assessment of the associated impact will be primarily from the side of the image. As the previous profile, they are highly concerned about how this marine pollution event can be transferred to the municipality's image, since the beach is a tourist attraction in Barcelona.

Both profiles know that the event is warned with a red flag placed by the Red Cross, the body that physically executes the change. However, there is a disparity in pointing to the authority responsible for closing the bath due to the discharge of untreated water. Different local organisations were cited: Maritime Rescue, Police, Aiguies de Barcelona (private water utility), Beaches and Gardens public department, and Barcelona City Council. Thus, it was observed that there is no clear identification of who is in charge of such management. A recurring complaint from the nautical rental businesses is the passivity with which the body responsible for setting the red flag acts, without communicating to the businesses the reason for the colour change. The affected businesses interested in the reason for setting the red flag have to go to the Red Cross or Maritime Rescue offices to find out.

During the interviews, it was informed to the interviewees that the City Council is responsible for the beach closing by setting a red flag. Both profiles indicate that it is a correct and necessary action; beachgoers cannot be allowed to enter into the sea without enough safety and health conditions. However, for profile 1 (i.e. water-sports businesses and fishermen), this action is not enough. They stated that the City Council should take other types of measures to avoid these events from happening.
The business owners and fishermen interviewed in Barcelona all agreed on the need for local authorities to provide better information about the risks to beachgoers and take preventive measures to avoid spills. The representatives of the nautical sports in the study reflected concern regarding the lack of clear information about the reasons for setting the red flag.

The interviewees highlighted two main measures: a campaign to raise awareness and a separate sewer system. The first measure stated that tourists and local visitors are informed about the weather, but not about the beach and the sea's general conditions. They are aware of plastic pollution but to a much lesser extent than from untreated water. Besides, in the interviewees' view, it would be valued if the City Council intervened, advising bathers on the steps to follow, such as visiting information panels to determine water quality status and, in case of the bath is allowed but a certain degree of pollution can be found in the seawaters, taking a shower after a bath.

On the other hand, they know that in other countries, the problem of "brown waters" has already been successfully acted upon with a double channelling of water that allows adequate disposal, on the one hand, wastewater, and, on the other, rainwater. The interviewees were not aware that runoff washes off pollutants deposited on urban surfaces and the discharge of pipes carrying only stormwater is also polluted. Then, this discharge of stormwater can make bathing unsafe for some days too.

Table 3 gathers some of the individual statements related to the different surveyed aspects for business owners and fishermen in Barcelona.

\subsection{Residents in Badalona and Barcelona}

This section presents the 10-min Computer-Assisted Telephone Interviewing results to residents in Badalona and Barcelona (Table 1).

The total respondents stated that they go to the beach for swimming, in addition to other complementary activities (Fig. 5). Thus, it can be assumed that during the bathing season, the prohibition on swimming affects all negatively in Barcelona and Badalona(Figs. 6, 7, and 8).

Barcelona's beachgoers do not seem used to checking the beach status (25\% responded always, $31 \%$ sometimes, and $44 \%$ never) and the ones that check its status do it through mobile apps and social 
Table 3 Some survey's statements of seafront business owners and fishermen in Barcelona

Knowledge of the event

Impact of the event

\begin{abstract}
Environmental (profile 1)
\end{abstract}

Health (profile 1)

Economic (profile 1)

Business and municipality image

(profile $1 \&$ 2)

Appraisal of the administrative authority management of CSO spills issues

(Profile $1 \& 2$ )

Measures/Actions proposed (Profile $1 \& 2$ )
"When it rains a lot, you find wipes, everything... we have even taken out kilos"

"Finding cigarette butts, cottonbuds, ... in the sea after a rainfall is the most common thing in the world"

"When you see that the sea is calm and you see a flag, if it has rained, you can imagine that it is because of one of these"

"This happens practically every time it rains, so as not to burst the sewage system ... when the river water reaches a limit, what is the general, large sewer is not divided to the top. There is a very high wall that divides the sewage from the river water. When it has rained a lot, and there is a rise in river water and the wall overflows, they end up mixing... therefore one part stays in the sewage treatment plant, and another part ends up in the sea" (profile 2)

"The water is not healthy. We notice this because for years there have been no mussels on the rocks of the breakwaters; mussels are an indicator that the water is not good"

"fungus in the eyes of the fish and on their scales. I take a fish out, and I know when it is sick, I do not take them" (profile 1)

"On rainy days if we have waves then we go out surfing surrounded by faeces, rats, ... and we suffer from this issue, colleagues have caught illnesses from surfing in polluted water. The passion for the sport is what it is; you get into the water even if it is dirty" (profile 1)

"For a couple of days or three, I try to look for other solutions such as trips to the coast"

"Before there were more sport fishing competitions on the beach in Barcelona, now less, we move them to other places where they can be held: Mataró, Castelldefels, ..."

"brown stain approaching the shore and smelling" (profile 1)

"The only problem it can give us is the smells when the wind is downwind of the restaurant the bad smell reaches us" (profile 2)

"The Red Cross already sees them, and they change the flag"

"I would go and talk to the sea rescue guys and ask them for explanations ... I always go myself; they have never called me"

"For me, the red flag is not the solution; for me, the solution is to go to the root of the problem and try to solve it"

"Sometimes the water is clear, and people think it is clean, but in reality, it is polluted, you should be clearer with bathers that it is polluted and then you have to take a shower ... people should not think that there is the only pollution from things floating in the water"

"We do not have this in Barcelona; right now, everything goes to the same place, it cannot stand the pressure, and we have to open up; this would be a brutal change" media (63\% in Barcelona and 64\% in Badalona). Another way to check the beach's status is through the City Councils websites (Badalona City Council, n.d.; Barcelona City Council, n.d.). The information provided regarding the beaches status is water quality, presence of jellyfish, sea conditions, occupation level, and colour of the flag (Fig. 9). The fact that a low percentage of respondents said checking the beach status could be interpreted as either lack of awareness of potential water quality issues or a lack of interest or understanding of available informative means to check the beach status before or once they arrive. To be highlighted is the higher percentage of Badalona beachgoers (37\%) that actively search the conditions of the beach and the sea. 
Fig. 5 Results obtained from surveyed residents $(n=$ sample size $)(1$ of 4$)$

Frequented beaches in Barcelona

Frequented beaches in Badalona

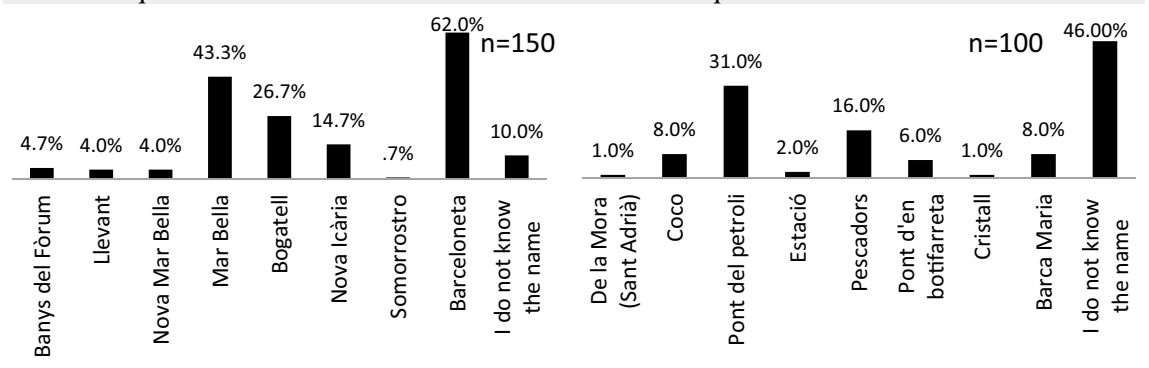

Type of activities undertaken at the beach

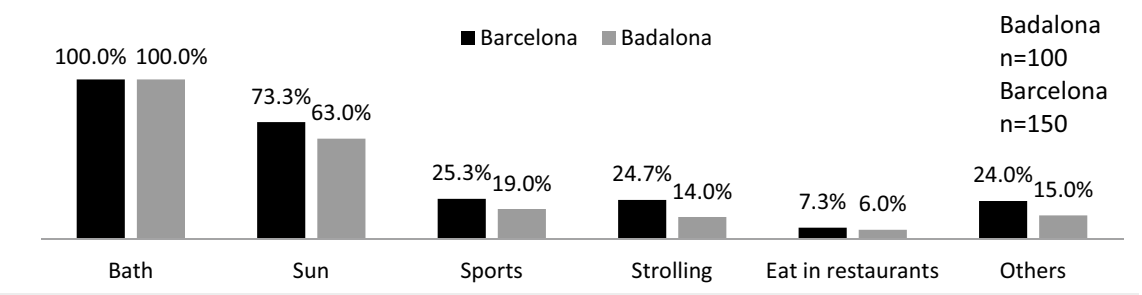

User willingness to find out about the conditions of the beach and the sea

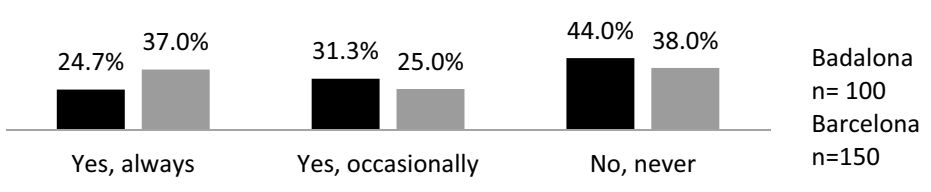

Water pollution is the fourth reason for a red flag (41\%) answered in Barcelona. However, it is the first option selected in Badalona (68\% of respondents) (Fig. 6). These results suggest that if weather conditions seem favourable, Barcelona residents might not be aware of possible health risks or misinterpret the red flag with other hazards, such as the presence of jellyfish. Similarly, most respondents do not relate CSO spills with a red flag (75\%) (Fig. 7). Furthermore, the following question, asking whether they have ever found a red flag at the beach caused by a CSO event, had a 55\% negative response (Fig. 8). On the contrary, Badalona residents are quite aware of the CSO spills, since they mainly relate water contamination with a red flag (68\%) (Fig. 6), and 50\% of the interviewees stated awareness of the existence of a red flag due to CSO spills after rainfall events (Fig. 7). Only $14 \%$ of them stated that they have never encountered any beach closure (red flag) because of CSO spills (Fig. 8).

The responsibility of the decision to close the beach or set the red flag does not seem to be evident amongst respondents in Barcelona (24\% for police and civil service in the first place, and $22 \%$ for the City Council) (Fig. 7). However, when asked about who is responsible for the water contamination caused by CSO spills, the majority (41\%) point to the City Council (Fig. 8). These answers suggest that citizens hold the City Council accountable for contaminating the seawater and its related health risk. However, they do not correlate the beach closure decision to them. On the other hand, Badalona residents identified as responsible for the decision in the first place to the City Council (40\%), followed by beach lifeguards (22\%). Similarly, most interviewees (41\%) in Badalona stated that the water contamination responsibility is the City Council (Fig. 8).

Regarding their opinion of the current water quality (Fig. 7), the analysis of Barcelona and Badalona samples residents combined indicates that the youngest segment of the sample (18-40 years old) is not very satisfied with it (Table 4) and shows a more demanding attitude. In contrast, older people (40-60 years old) are very satisfied with the current water status. It seems that the latter can appreciate the efforts made during the past years to improve the water quality.

Most interviewees (more than $80 \%$ in Badalona and Barcelona) agree with prohibiting bathing after a CSO 
Fig. 6 Results obtained from surveyed residents $(n=$ sample size $)(2$ of 4$)$
Through what means the user receives information about the status of the beach
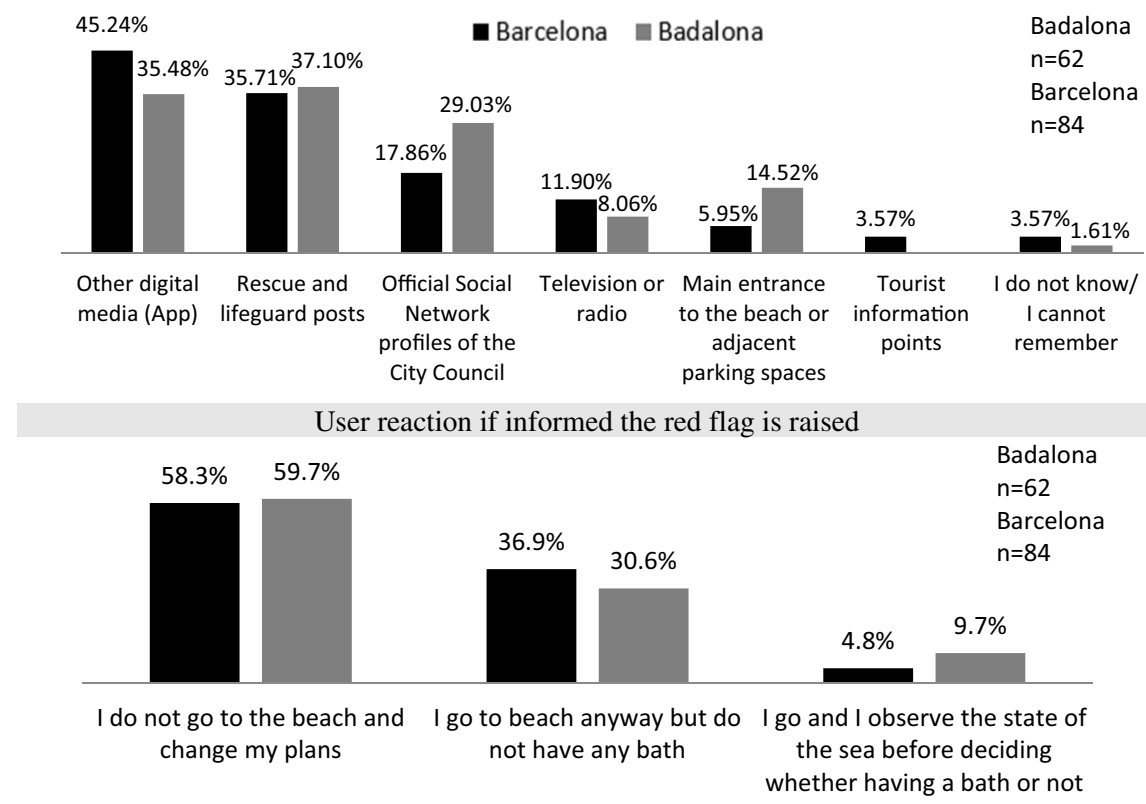

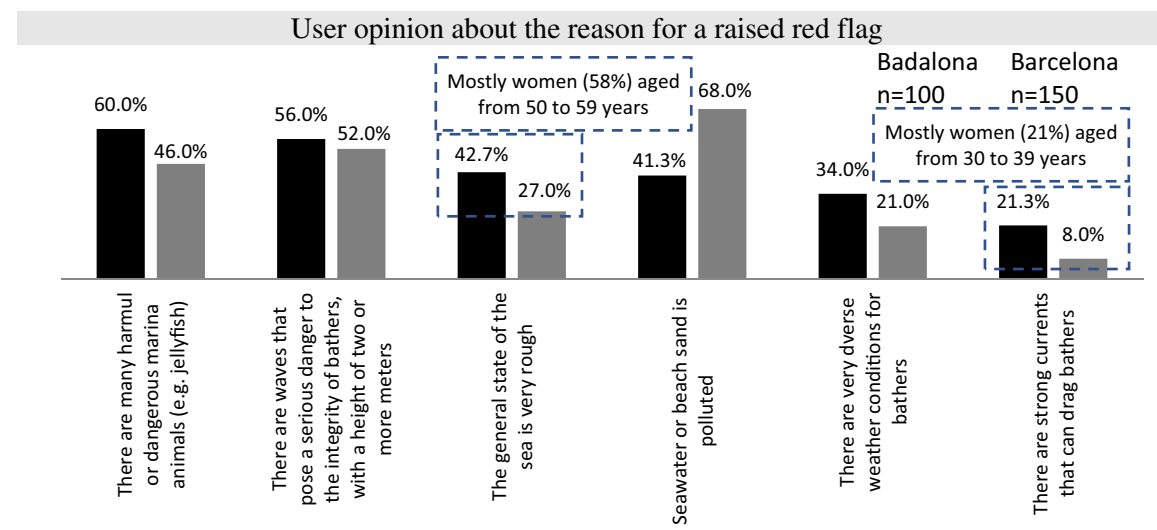

event (Fig. 8). This may reflect support for the City Councils in this regard, although there is general disagreement with the fact that CSO spill events occur.

Concerning the potential economic losses caused by CSO events, it is noteworthy that more than half of the sample $(58.3 \%)$ change their plans if there is a red flag, which provides information about the potential loss of revenues for the businesses of the area.

The fact that the surveys were not carried out on-site during the bathing season and the sample sizes (150 in Barcelona and 100 in Badalona) taken may limit the statistical capability. The time gap between the study and the last bathing season may also bias the results. To conclude, it would be valuable for decision-makers to consider carrying out a comprehensive economic valuation of the different measures available to prevent or reduce overflows into the natural system. However, it is acknowledged the need to incorporate tourists, as they are the ones that likely contribute to major income, for a future survey to provide a more comprehensive understanding of the damages caused by CSO spills into bathing coastal areas.

\subsection{Discussion}

Business owners seem better informed than residents of whom most do not understand well who is responsible for managing CSO events. The residents 
Fig. 7 Results obtained from surveyed residents ( $n=$ sample size) (3 of 4$)$

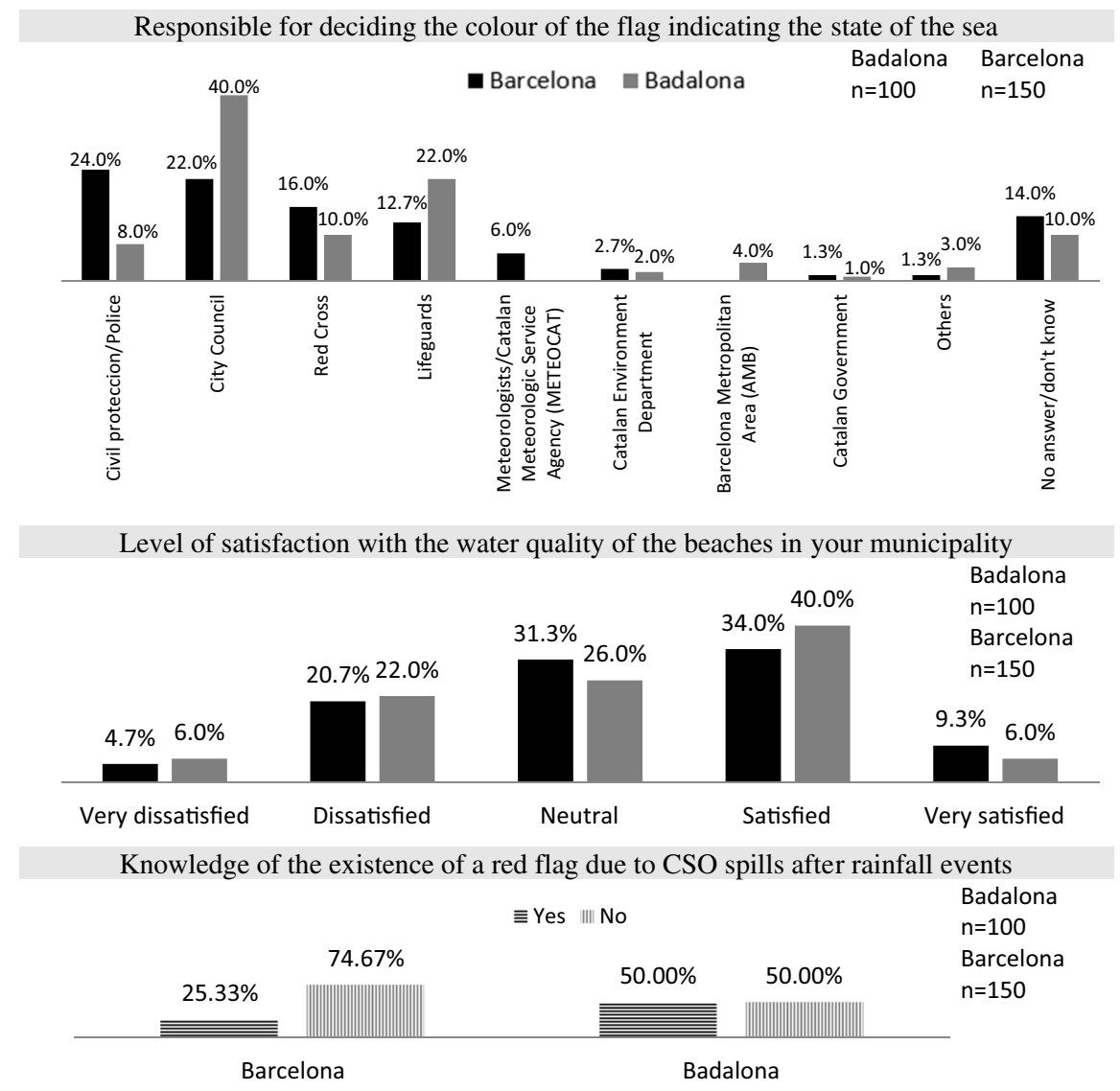

interviewed mostly blame their City Councils for the consequences of these spills. Overall, they cannot distinguish between municipality-managed sewers and the main sewers managed by the supramunicipal authority AMB. They identify the City Council as responsible for setting the red flag. Therefore, the complexity in terms of governance negatively affects the City Councils, since this misunderstanding contributes to a bad reputation for the City Council. Better communication about the different authorities' competencies and the characteristics and limitations of combined sewers could benefit the City Council reputation in this regard.

The results suggest that more informative campaigns in Barcelona may positively raise awareness of potential health risks under bad water quality conditions and the importance of following the recommendations of flag colours and other signs. In contrast, business owners, fishermen, and residents in Badalona know the problem and its main consequences better.
It has to be highlighted that the youngest segment of the sample in both Barcelona and Badalona (18-40 years old) shows a more demanding attitude by stating their discontent with the current water quality of the beaches. On the other hand, older people (40-60 years old) are quite or very satisfied with the current water status. This older segment of the sample seems to appreciate the efforts made during the past years to improve the beach quality, according to their anecdotal comments in the telephone surveys.

Although both municipalities are very close, the differences in perceiving the problem are remarkable. Badalona's residents know of the problem, and they show significant concern about it. They see their beaches as a significant asset for their city. In contrast, Barcelona's residents interviewed mostly do not show such big concern about protecting their beaches. They do not even know much about it. Also, differences can be found between 
Fig. 8 Results obtained from surveyed residents $(n=$ sample size $)(4$ of 4$)$

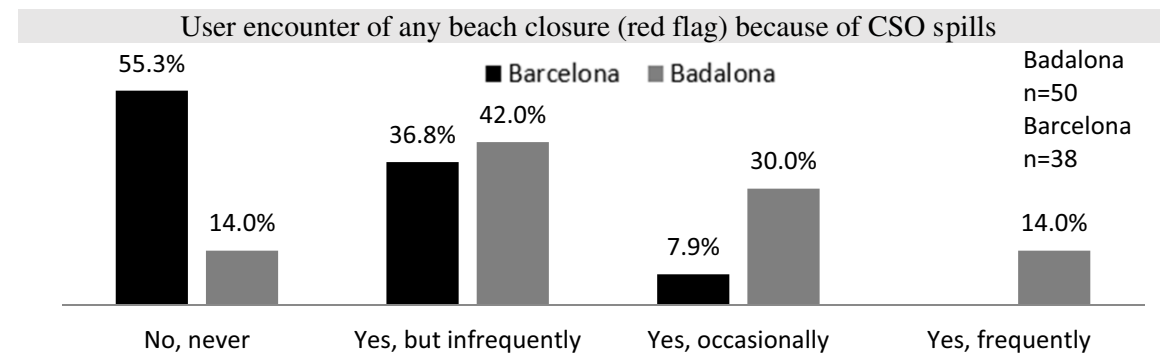

User opinion about the responsibility for seawater pollution caused by CSO spills into the

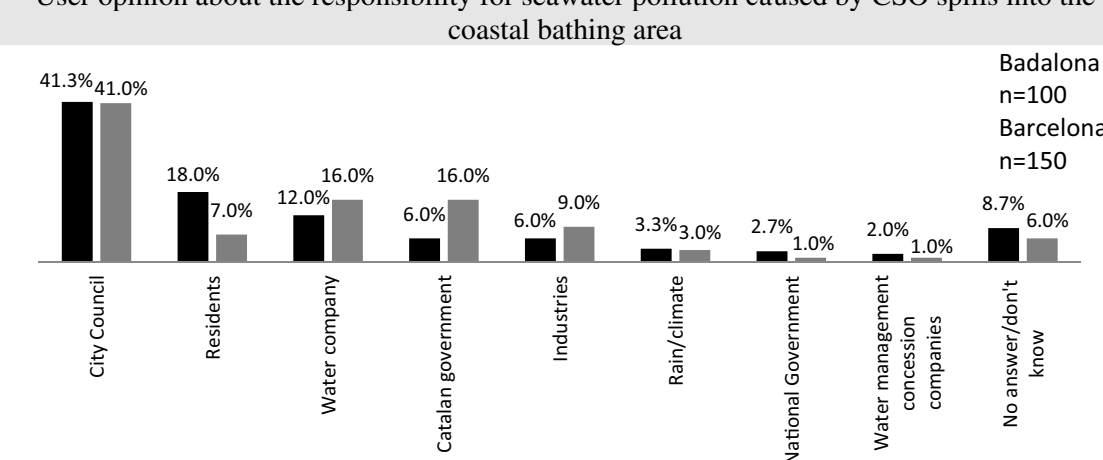

User agreement regarding beach closures due to CSO spills into bathing coastal areas

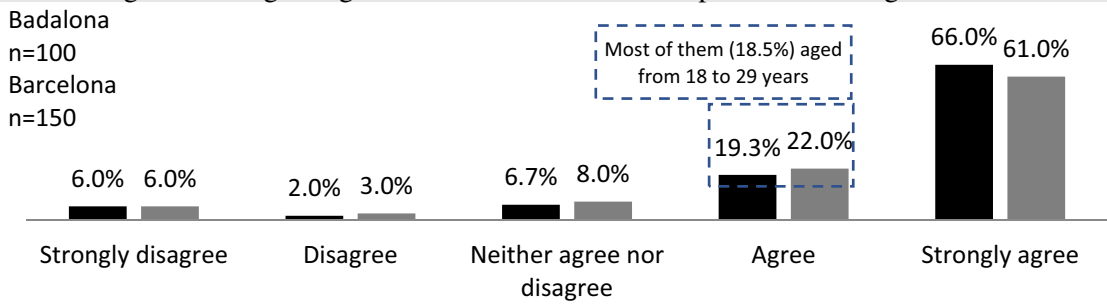

the business owners and fishermen interviewed in both cities. While in Barcelona, two profiles were distinguished based on their position regarding the event; in Badalona, this differentiation was not perceived.

From the economic point of view, restaurant owners do not perceive cancellations of reservations due to beach closures because of low water quality. It seems that restaurant cancellations are related to weather issues more than to CSO spills (and other reasons for setting a red flag). What is clear is the negative impact on the municipality's image, affecting Barcelona's tourist sector.

Interviewees in Badalona and Barcelona proposed improvement measures but did not know the technical details of carrying them out. A cost-benefit analysis (CBA) must be undertaken to check the feasibility of any improvement and its implementation. Montserrat (2015) stated that replacing every existing combined sewer system with separate ones would become cost-prohibitive and impractical for most municipalities.

\section{Conclusions}

In this study, through qualitative survey-based analysis, the potential impacts of CSO spills into coastal bathing areas have been analysed. Two neighbouring and seaside Spanish municipalities, Badalona and Barcelona, were selected as case studies. As the first group, seafront business owners and fishermen were surveyed to understand how extent CSO spills are, and their corresponding beach closures might affect their business from an economic point of view. The second group, residents, were surveyed to analyse their perception regarding this issue. 


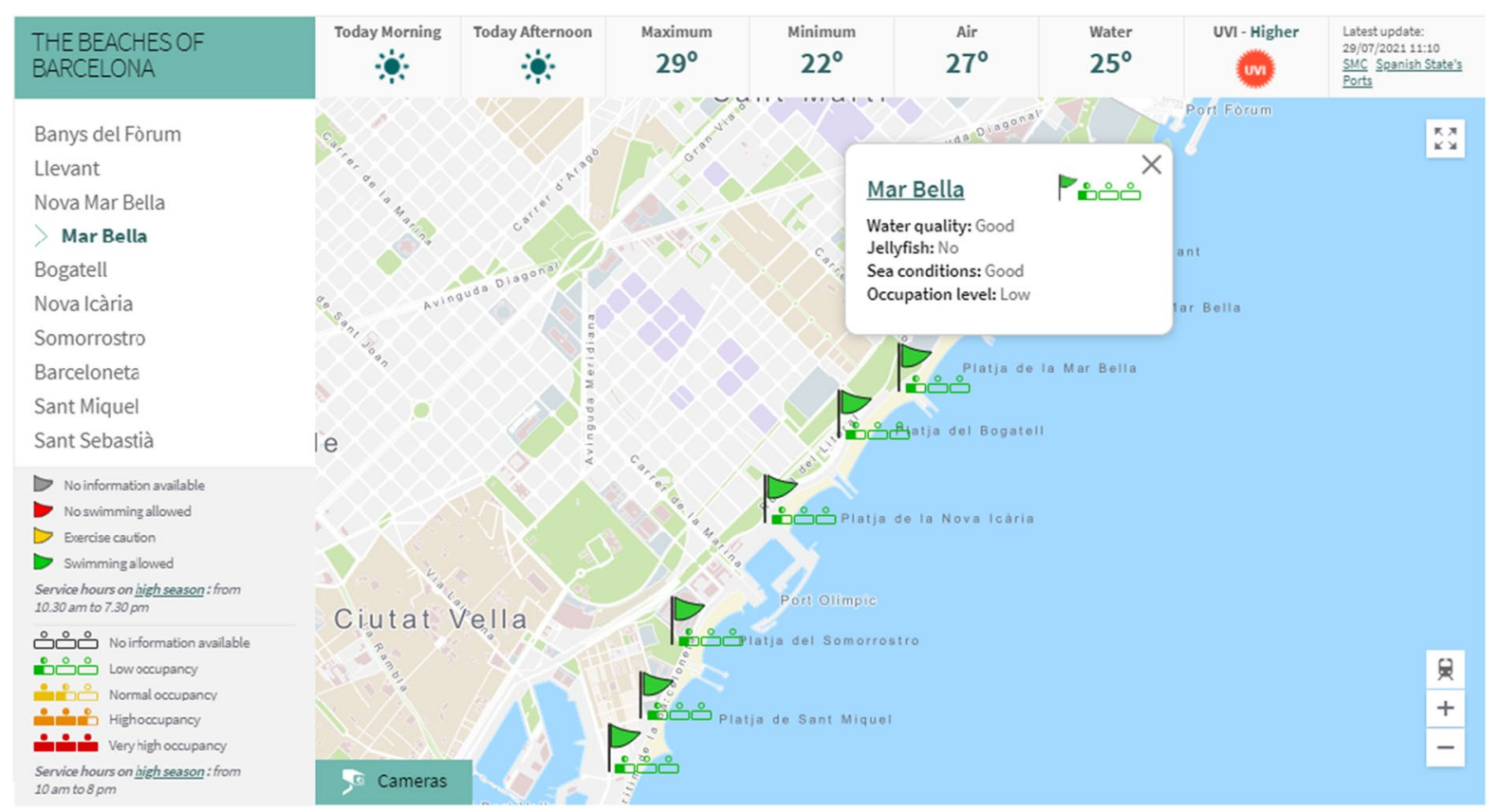

Fig. 9 Beaches status through Barcelona City Council website (Barcelona City Council n.d.)

Table 4 Level of satisfaction of Badalona and Barcelona resident with the water quality of the beaches

\begin{tabular}{llllll}
\hline & Age & & & & \\
\cline { 2 - 6 } & $18-29$ & $30-39$ & $40-49$ & $50-59$ & $\geq 60$ \\
\hline Very dissatisfied & $6 \%$ & $8 \%$ & $10 \%$ & $2 \%$ & $0 \%$ \\
Dissatisfied & $\mathbf{3 4 \%}$ & $\mathbf{3 2 \%}$ & $12 \%$ & $20 \%$ & $8 \%$ \\
Neutral & $30 \%$ & $38 \%$ & $38 \%$ & $20 \%$ & $20 \%$ \\
Satisfied & $28 \%$ & $22 \%$ & $24 \%$ & $\mathbf{5 0 \%}$ & $\mathbf{5 8 \%}$ \\
Very satisfied & $2 \%$ & $0 \%$ & $\mathbf{1 6 \%}$ & $8 \%$ & $14 \%$ \\
\hline
\end{tabular}

The direct relation between CSO spills and restaurants economic impact is not observed since business owners in Badalona and Barcelona do not perceive any revenue impacts due to these events. Their main concern is the municipality's image, which indirectly might affect the tourist sector, especially in Barcelona. Managers of other businesses that connect directly with the seawater (nautical sports and fishermen) recognise the economic impact of CSO spills and the resulting red flag. However, they cannot elicit an estimate.

Residents' perceptions of CSO spills are remarkably different in both cities. In Badalona, they know quite the problem and identify correctly the responsibility for setting the red flag and the beach closure (i.e. the municipality); Barcelona residents are confused about this. If weather conditions seem favourable, Barcelona residents might not be aware of possible health risks or mislead the red flag by other hazards, such as the presence of jellyfish. As most people check the beach status do it through mobile apps and social media, it is recommended that the information dissemination is enhanced through these channels and the traditional flags in the rescue posts.

Governance in terms of CSO spills is mostly unknown among Barcelona residents, and to a lesser extent for Badalona. The roles and competencies in sewer systems management of the different institutions at various levels (local, supramunicipal, and national) are complex to understand. Therefore, better communication with the citizens to avoid an unnecessary loss of trust in the City Council is required. In particular, as stated by the interviewees, helpful information about the reasons for setting the red flag is necessary. Also, businesses located in the affected areas demand to be better informed by the sewer systems' responsible bodies and authorities. 
In this context, decision-makers and stakeholders should be interested in understanding the perception of affected users upon these events to take appropriate measures to enhance awareness programs or measures to reduce overflows.

Acknowledgements The authors thank the financial support of the European Commision under its funding programme H2020 for the projects RESCCUE and BINGO.

Author contribution Conceptualization, M.G.H. and E.M.G.; methodology, M.G.H. and E.M.G.; validation, M.G.H. and E.M.G.; formal analysis, M.G.H., E.M.G., E.FO., and S.G.; investigation, M.G.H.; data curation, M.G.H.; writing, original draft preparation, E.M.G.; writing, review and editing, M.G.-H., E.M.G., E.FO., and S.G.; supervision, E.M.G.; project administration, E.M.G.; funding acquisition, E.M.G. and M.G.H. All authors have read and agreed to the published version of the manuscript.

Funding Open Access funding provided thanks to the CRUE-CSIC agreement with Springer Nature. This work has been conducted with the financial support of the European Commission under its $\mathrm{H} 2020$ funding programme. Particularly, the projects RESCCUE Grant Agreement No. 700174 and BINGO (Grant Agreement No. 641739).

Data availability The minimal dataset to interpret the results is presented in this same manuscript.

\section{Declarations}

Ethics approval and consent to participate Not applicable.

Consent for publication The publication of the tweets showed in Fig. 4 was allow by the Twitter account owner (@ BadalonaMar).

Competing interests The authors declare that they have no competing interests.

Open Access This article is licensed under a Creative Commons Attribution 4.0 International License, which permits use, sharing, adaptation, distribution and reproduction in any medium or format, as long as you give appropriate credit to the original author(s) and the source, provide a link to the Creative Commons licence, and indicate if changes were made. The images or other third party material in this article are included in the article's Creative Commons licence, unless indicated otherwise in a credit line to the material. If material is not included in the article's Creative Commons licence and your intended use is not permitted by statutory regulation or exceeds the permitted use, you will need to obtain permission directly from the copyright holder. To view a copy of this licence, visit http://creativecommons.org/licenses/by/4.0/.

\section{References}

Badalona City Council. (n.d.). Barcelona beaches state. http:// badalona.cat/portalWeb/badalona.portal?_nfpb=true\&_ pageLabel=estatPlatges\#wlp_estatPlatges. Accessed 29 July 2021.

Barcelona City Council. (n.d.). Bathing and beaches. https:// www.barcelona.cat/en/what-to-do-in-ben/bathing-andbeaches. Accessed 29 July 2021.

Butler, D., Digman, C. J., Makropoulos, C., Davies, J. W., Digman, C. J., Makropoulos, C., \& Davies, J. W. (2018). Urban Drainage, Fourth Edition. CRC Press. https://doi. org/10.1201/9781351174305.

Comas, P., Falcó, X., García, J., Malgrat, P., Sunyer, D., Villanueva, Á., et al. (2014). Manual Nacional de Recomendaciones para el Diseño de Tanques de Tormenta (1st ed.). Madrid, Spain: Ministerio de Agricultura, Alimentación y Medio Ambiente (MAGRAMA). https://www. asoaeas.com/sites/default/files/Documentos/Manual_ Tanques_Tormenta_MAGRAMA.pdf.

Corominas, L., Acuña, V., Ginebreda, A., \& Poch, M. (2013). Integration of freshwater environmental policies and wastewater treatment plant management. Science of the Total Environment, 445-446, 185-191. https://doi.org/10. 1016/J.SCITOTENV.2012.12.055.

España. (2015). Ley 22/1988, de 28 de julio, de Costas (Last updated 11 December 2015). Madrid, Spain: Boletín Oficial del Estado (BOE). https://www.boe.es/buscar/act. php?id=BOE-A-1988-18762.

European Commission. (2019a). Evaluation of the Urban Waste Water Treatment Directive. https://ec.europa.eu/ environment/water/water-urbanwaste/pdf/UWWTD Evaluation SWD 448-701 web.pdf.

European Commission. (2019b). The European Green Deal. COM/2019/640 final. Brussels, Belgium: European Comission. https://eur-lex.europa.eu/legal-content/EN/TXT/?uri= CELEX:52019DC0640.

Geels, F. W. (2006). The hygienic transition from cesspools to sewer systems (1840-1930): The dynamics of regime transformation. Research Policy, 35(7), 1069-1082. https://doi.org/10.1016/J.RESPOL.2006. 06.001 .

Gromaire, M. C., Garnaud, S., Saad, M., \& Chebbo, G. (2001). Contribution of different sources to the pollution of wet weather flows in combined sewers. Water Research, 35(2), 521-533. https://doi.org/10.1016/ S0043-1354(00)00261-X.

ICC (the International Chamber of Commerce), \& ESOMAR. (2016). International code on market, opinion and social research and data analytics. Amsterdam, The Netherlands. https://www.esomar.org/uploads/public/knowledge-and-standards/ codes-and-guidelines/ICCESOMAR_Code_Engli sh_.pdf.

International Organization for Standardization [ISO]. (2019). ISO 20252:2019 Market, opinion and social research, including insights and data analytics vocabulary and service requirements. Geneva, Switzerland: International Organization for Standardization. https://www.iso.org/standard/73671.html. 
Krichak, S. O., Tsidulko, M., \& Alpert, P. (2000). Monthly synoptic patterns associated with wet/dry conditions in the Eastern Mediterranean. Theoretical and Applied Climatology, 65(3-4), 215-229. https://doi.org/10.1007/ s007040070045.

Malgrat, P., Sunyer, D., \& Russo, B. (2015). Las nuevas exigencias sobre las explotaciones de saneamiento derivadas de la aplicación del Real Decreto 1290/2012. In IV Jornadas de Ingeniería del Agua. La precipitación y los procesos erosivos (p. 8). Córdoba, Spain. http://www.ingen ieriadelagua.com/2004/JIA/Jia2015/c/c015.pdf.

Marsalek, J., Barnwell, T. O., Geiger, W., Grottker, M., Huber, W. C., Saul, A. J., et al. (1993). Urban Drainage Systems: Design and Operation. Water Science and Technology, 27(12), 31-70. https://doi.org/10.2166/wst.1993.0291.

Ministerio de agricultura, alimentación y medio ambiente. (2014). Orden AAA/2056/2014, de 27 de octubre, por la que se aprueban los modelos oficiales de solicitud de autorización y de declaración de vertido. Madrid, Spain. https://www.boe.es/boe/dias/2014/11/05/pdfs/BOE-A2014-11411.pdf.
Ministerio de Agricultura Alimentación y Medio Ambiente. (2017). Real Decreto 876/2014, de 10 de octubre, por el que se aprueba el Reglamento General de Costas (Last updated 12 January 2017) . Madrid, Spain: Boletín Oficial del Estado (BOE).

Montserrat, A. (2015, July 3). Towards better management of combined sewer systems. A methodology based on lowcost monitoring. TDX (Tesis Doctorals en Xarxa). Universitat de Girona. Retrieved from https://dugi-doc.udg.edu/ handle/10256/12568.

Suárez López, J. J., Puertas, J., Anta, J., Jácome, A., \& Álvarez-Campana, J. M. (2014). Integrated management of water resources in urban water system: Water Sensitive Urban Development as a strategic approach. Ingeniería Del Agua, 18(1), 107. https://doi.org/10.4995/ia.2014. 3173.

Publisher's Note Springer Nature remains neutral with regard to jurisdictional claims in published maps and institutional affiliations. 